Original Research Paper

\title{
KKN Era New Normal Aktifasi Website SID dan Penanganan Masalah Administrasi Data Penduduk Desa Labuhan Haji
}

\author{
Ahmad Jupri ${ }^{*}$,Eka S Prasedya ${ }^{2}$, Tapaul Rozi ${ }^{3}$, Ahdiat Aunul Hipzi ${ }^{4}$, Harun Abdat \\ ${ }^{1}$ Program studi Ilmu Lingkungan FMIPA Universitas Mataram \\ ${ }^{2}$ Program Studi Biologi FMIPA Universitas Mataram \\ ${ }^{3}$ Fakultas Peternakan Universitas Mataram \\ ${ }^{4}$ Jurusan Teknik Elektro Fakultas Teknik Universitas Mataram \\ ${ }^{5}$ Program Studi Komunikasi Fisipol Universitas Mataram
}

https://doi.org/10.29303/jpmpi.v3i2.923

Sitasi: Jupri, A., Prasedya, E. S., Rozi, T., Hipzi, A. A., \& Abdat, H. (2021). KKN Era New Normal Aktifasi Website SID dan Penanganan Masalah Administrasi Data Penduduk Desa Labuhan Haji. Jurnal Pengabdian Magister Pendidikan IPA, 4(3)

\section{Article history}

Received: 31 Juli 2021

Revised: 31 Agustus 2021

Accepted: 4 September 2021

*Corresponding Author: Ahmad

Jupri, Program studi Ilmu Lingkungan FMIPA Universitas Mataram, Indonesia;

Email: Juprizikril@ gmail.com

\begin{abstract}
Program KKN Tematik di Era New Normal merupakan salah satu bentuk pengabdian kepada masyarakat yang dilakukan oleh mahasiswa sebagai salah satu wujud implementasi Tri Dharma Perguruan Tinggi, yang dipadukan pelaksanaan manajemen dan waktunya dengan kegiatan yang selalu memperhatikan protokol kesehatan disetiap kegiatan. Program kerja utama dalam KKN bertema Desa Digital ini adalah menangani permasalahan yang terjadi pada pengelolaan administrasi data desa dan pelayanan berupa penyebaran informasi tentang desa kepada para penduduk desa Labuan Haji. Dalam penyebaran informasi tersebut dilakukan pengaktivasian sebuah website open SID yang sebelumnya sudah dikativasi namun sekarang sudah mati karena kurangnya pe ngelolaan dari staff desa
\end{abstract}

Keywords: KKN tematik, new normal, SID

\section{Pendahuluan}

Program KKN Tematik di Era New Normal merupakan salah satu bentuk pengabdian kepada masyarakat yang dilakukan oleh mahasiswa sebagai salah satu wujud implementasi Tri Dharma Perguruan Tinggi, yang dipadukan pelaksanaan manajemen dan waktunya dengan kegiatan yang selalu memperhatikan protokol kesehatan disetiap kegiatan. KKN Tematik sebagai proses pembelajaran bagi mahasiswa sekaligus wahana pemberdayaan masyarakat. KKN Tematik ini direncanakan, dan dilaksanakan secara sistematis berdasarkan tema yang digali dari potensi masyarakat, dirumuskan, dan dilaksanakan bersama masyarakat. Hal ini diharapkan dapat memacu kemampuan masyarakat dalam pengembangan diri dan wilayah sehingga kesejahteraannya meningkat.

Program Kuliah Kerja Nyata (KKN) yang bertemakan Desa Digital merupakan sebuah program digitalisai desa yang bertujuan untuk membangun sistem pengelolaan sumber daya maupun administrasi data desa agar dapat beradaptasi di era modern ini. Program KKN bertemakan Desa Digital ini diharapkan dapat mudah pengaksesan informasi desa yang sejalan dengan era Industri IV saat ini. Sehingga dapat mengurangi permasalahan dipengelolaan data dan informasi dalam ruang lingkup desa.

Salah satu tempat terpilih yang dijadikan lokasi pengabdian mahasiswa KKN adalah Desa 
Labuhan Haji, Kecamatan Labuhan Haji, Kabupaten Lombok Timur. Desa Labuhan Haji adalah salah satu dari sekian banyak desa di Kecamatan Labuhan Haji yang sektor ekonominya terdampak akibat covid-19. Adanya permasalahan yang dialami baik itu pada bagian Website maupun pengelolaan administrasi data penduduk desa Labuhan Haji maka kami sebagai Mahasiswa KKN TEMATIK bertemakan Desa Digital dapat membantu pekerjaan kepala desa dan staff kantor pemerintahan desa dan mewujudkan profesional pekerjaan kepala desa dan staff pemerintahan desa.

\section{Metode}

Metode penelitian ini terbagi ke beberapa bagian yaitu:

1) Metode Observasi

Metode observasi atau pengamatan adalah alat pengumpulan data yang dilakukan dengan cara mengamati dan mencatat secara sistematik gejala-gejala yang ada di tempat penelitian (Newman, 2013). Pada metode pengamatan ini, penulis terjun langsung untuk mengamati secara langsung terhadap pelaksanaan KKN, kegiatan-kegiatan dan fenomena-fenomena sosial yang terjadi sebagai dampak dari pelaksanaan KKN yang diterapkan. Data yang diperlukan dalam metode pengamatan ini adalah mengamati secara langsung di lokasi (Mason, 2002).

2) Metode Interview

Metode ini disebut juga dengan metode wawancara, yaitu suatu metode pengumpulan data yang dilakukan melalui tanya jawab secara langsung dengan sumber (Merriam, 2015). Interview merupakan alat pengumpulan informasi dengan cara mengajukan pertanyaan secara lisan, untuk dijawab secara lisan juga, ciri utama dari interview adalah kontak langsung dengan tatap muka antara pencari informasi dengan sumber informasi. Wawancara secara mendalam ini dilakukan oleh peneliti terhadap informan yang menjadi obyek dari penelitian ini yaitu kepala dusun, PKK, PEMDes dan BUMDes serta Karang Taruna Desa Labuhan Haji. Wawancara ini bertujuan untuk memperoleh informasi yang ada relevansinya dengan pokok persoalan penelitian di Desa Labuhan Haji.
3) Metode Dokumentasi

Dalam penelitian kualitatif terdapat sumber data yang berasal dari manusia seperti dokumen berupa foto dan bahan statistik (Fathoni, 2006). Metode dokumentasi ini merupakan salah satu bentuk pengumpulan data yang paling mudah. Dokumen yang diperlukan dalam penelitian ini meliputi kepala dusun, PKK, PEMDes dan BUMDes serta Karang Taruna Desa Labuhan Haji. Adapun data-data lain yang dibutuhkan untuk melengkapi penyusunan laporan ini seperti dokumentasi dalam penelitian KKN.

Seluruh rangkaian kegiatan dilakukan melalui beberapa tahap seperti tahap persiapan, sosialisasi program, serta evaluasi dan monitoring.

1) Tahap Persiapan

Sebelum memulai kegiatan KKN, disiapkan terlebih dahulu surat pengantar KKN dan izin kepada kepala desa untuk melakukan kegiatan KKN didesa Labuhan Haji. Secara umum ada dua program wajib yang akan dilaksanakan oleh mahasiswa selama KKN yaitu sosialisasi dan pematangan atau pemantapan program Mahadesa. Dengan kedua program tersebut diharapkan terlaksana dengan baik dan dapat memberikan manfaat bagi desa dan masyarakatnya.

2) Sosialisasi Program

Kegiatan sosialisasi ditargetkan pada staff kantor pemerintah desa. Pada kegiatan tersebut kami akan menjelaskan maksud dan tujuan pelaksanaan kegiatan serta memperkenalkan metode dan media yang digunakan dalam kegiatan tersebut.

3) Monitoring

Dilakukan dengan cara mengecek apakah program sosialisasi yang dilakukan berjalan atau tidak dengan cara berkunjung kedesa tempat sosialisasi dalam kurun 3 pekan setelah tahap sosialisasi.

\section{Hasil dan Pembahasan}

Program kerja utama dalam KKN (Kuliah Kerja Nyata) tematik Desa Labuhan Haji era new normal ini adalah menangani permasalahan yang terjadi pada pengelolaan administrasi data desa dan pelayanan berupa penyebaran informasi tentang desa kepada para 
penduduk desa Labuan Haji. Dalam penyebaran informasi tersebut dilakukan pengaktivasian sebuah website open SID yang sebelumnya sudah dikativasi namun sekarang sudah mati karena kurangnya pe ngelolaan dari staff desa. Pada KKN tematik ini program kerja utama yang akan dikerjakan adalah menangani website SID yang mati dan sudah tidak beroperasi lagi. Berikut merupakan kegiatan yang dilakukan KKN tematik tema Desa Digital di Desa Labuan Haji :

1) Aktivasi Website SID kantor desa Labuan Haji Tahap awal yang dilakukan dalam proses aktivasi website kami melakukan diskusi dengan pihak desa terutama bagian yang mengelola website SID tersebut mengenai permasalah seperti apa yang dialami sehingga website SID yang lama bisa mati selain itu disini kami juga memaparkan rencana kami untuk mengaktivasi website SID yang lama dengan beberapa perubahan yang terdiri dari tampilan,menambah tools pada website serta membuat website bisa digunakan dengan jauh lebih mudah terutama dalam pengimputan data ke databasenya, setelah memberitahukan rencana kami , tahap pertama yang kami lakukan berdiskusi kembali dengan pihak desa mengenai desain dari website sehingga website yang akan di pergunakaan ini bisa nyaman digunakan oleh pihak desa serta tidak merubah hal- hal penting yang ada di website sebelumnya, tahap selanjutnya yang kami lakukan pengumpulan data- data yang ada di database website SID yang lama untuk diimputkan kembali kedatabase website SID yang baru mengapa menggunakan data yang lama karena dalam datebase website SID yang lama sudah terimput data-data penduduk labuhan haji secara lengkap sehingga bila tidak menggunakan data tersebut maka perlu membutuh waktu beberapa bulan untuk membuat database tersebut. Setelah website selesai kami melakukan sosialisasi serta mengajarkan staff desa yang memiliki bagian pengelolaan website cara menggunakan website yang baru dari cara pengimputan data cara mengecek kesalahan data, cara mengeditnya serta memberitahukan beberapa tools yang di tambahkan website tersebut sehingga setelah kkn yang kami lakukan pihak desa bisa terus menggunakan website SID tersebut tanpa kebingungan dalam pengelolaanya.

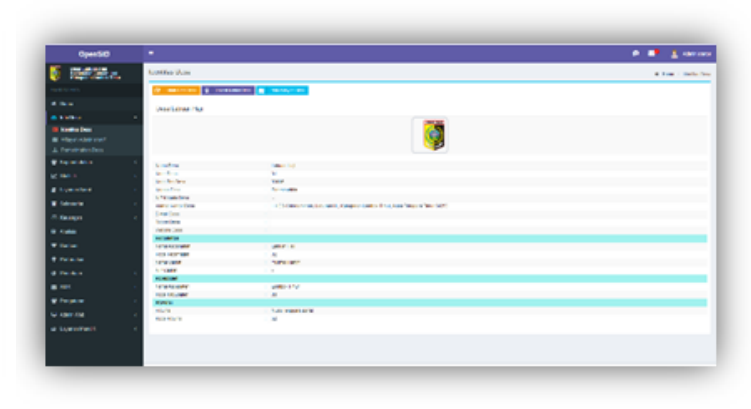

Gambar 1. Tampilan interface admin dari Website SID

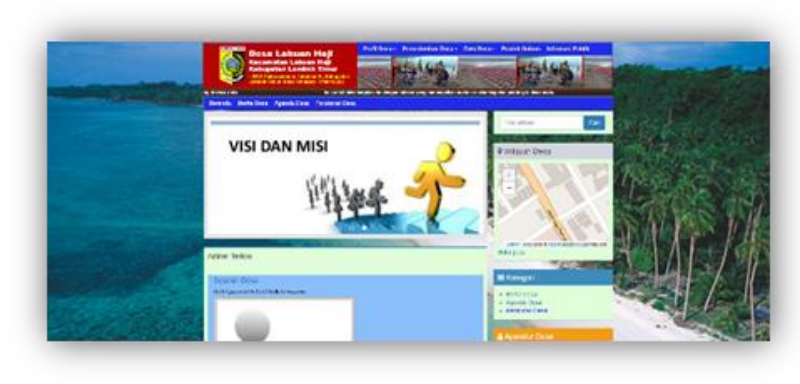

Gambar 2. Tampilan interface Website SID

2) Pengelolaan Data Penduduk Desa Labuan Haji

Setalah berdiskusi dengan pihak kantor desa labuhan haji terkait proker lain yang bisa dikerjakaan terutama yang berkaitan dengan digital pihak desa labuhan haji mengusulkan membantu mengelola data penduduk labuhan haji karena pada saat ini pemerintah meminta setiap desa untuk melakukan pendataan penduduk melalui online jika tidak melakukan pendataan tersebut pemerintah bisa saja mengurangi bantuan-bantuan yang akan di berikan ke pemerintahan desa. Yang kami kerjakan pertama kali dalam pengelolaan data penduduk yaitu mengumpulkan kk dari 9 dusun di labuhan haji serta mengumpulkan hasil survai yang pernah di lakukan pihak kantor desa labuhan haji mengenai keadaan penduduk dari pekerjaan, keadaan rumah hingga jumlah penghasilan selama 1 bulan data ini yang akan dipergunakan dalam pengimputan data. Selanjutnya melakukan pengimputan data penduduk dari 9 dusun di 
labuhan haji yang dimana pengimputan data penduduk ini di lakukan cukup lama karena jumlah penduduk yang banyak serta terganganggu oleh server dukcapil yang kadang mengalami beberapa masalah jika pengimputan data terlalu banyak dalam satu hari, setalah pengimputan selesai di lanjutkan dengan melakukan pengecekan data-data yang bercoret marah serta memperbaiki data tersebut sehingga bisa masuk ke server dukcapil setalah itu dilajutkan dengan pembekapan data untuk pihak desa labuhan haji serta membantu mengupload data ke server dukcapil.

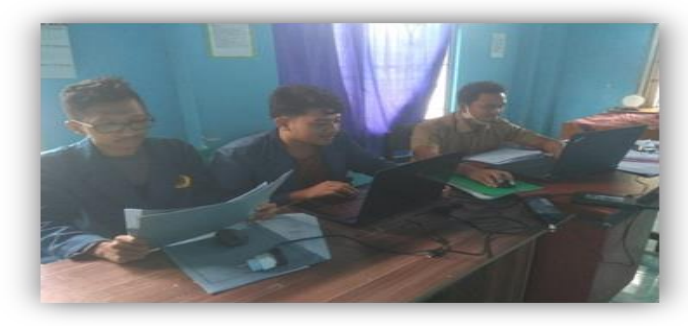

Gambar 3. Pengelolaan data penduduk desa Labuan Haji

Selain melakukan program kerja utama yaitu sosialisasi mengenai program Mahadesa TDC (Trade Distribution Center), dilakukannya juga program kerja tambahan sebagai berikut.

1) Mengajar Mengaji di TPQ Ambengan dan TPQ Esot

Dilakukannya kegiatan mengajar mengaji anak-anak pada TPQ di Dusun Ambengan setiap hari Senin, Selasa, Kamis, Sabtu, dan Minggu. Selain itu, dilakukan juga kegiatan mengajar mengaji anak-anak pada TPQ di Dusun Esot setiap hari Rabu dan Jumat. Kegiatan ini dilakukan dengan tujuan agar anak-anak semangat dalam belajar mengaji atau membaca Al-Qur'an sehingga kelak dapat diterapkan dan menjadi keseharian dalam kehidupan.

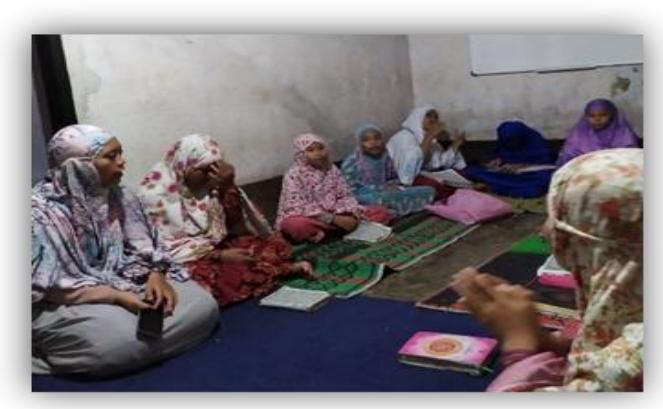

Gambar 4. Mengajar Mengaji di TPQ Ambengan

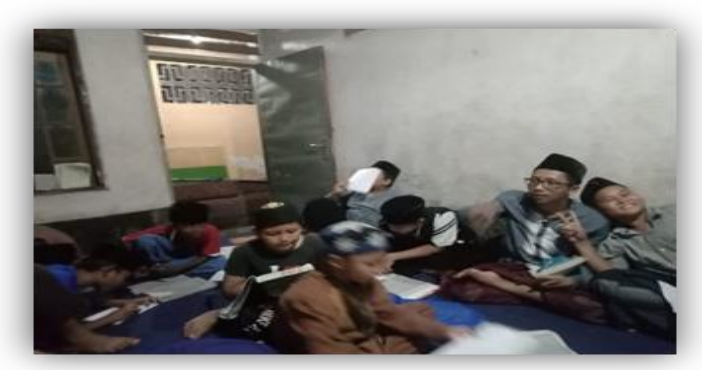

Gambar 5. Mengajar Mengaji di TPQ Ambengan

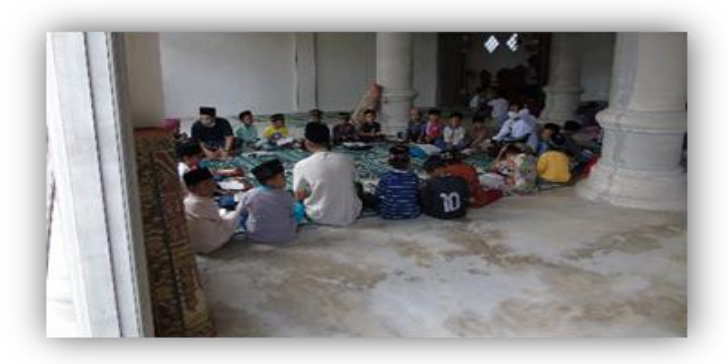

Gambar 6. Mengajar Mengaji di TPQ Esot

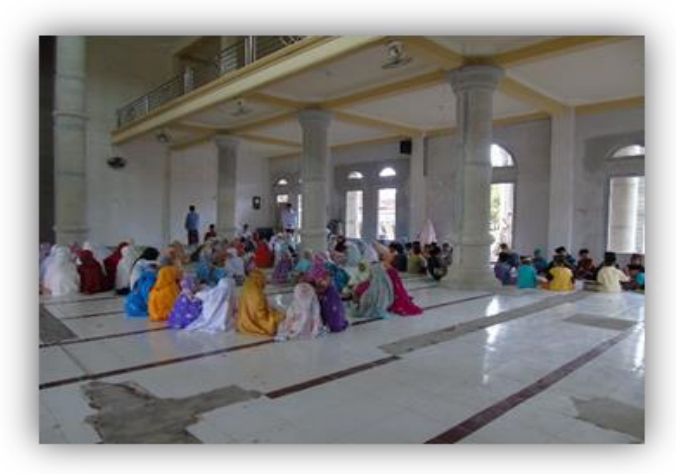

Gambar 7. Mengajar Mengaji di TPQ Eso 
2) Mengadakan Lomba di TPQ Ambengan

Pada minggu terakhir mengajar mengaji, diadakannya kegiatan lomba praktik sholat, hafalan surat pendek, adzan, dan cerdas cermat tajwid di TPQ Ambengan. Kegiatan ini dilakukan sebagai bentuk luaran dari kegiatan mengajar mengaji serta sebagai bentuk apresiasi kepada anak-anak di TPQ Ambengan yang selalu bersemangat untuk belajar mengaji atau membaca Al-Qur'an.

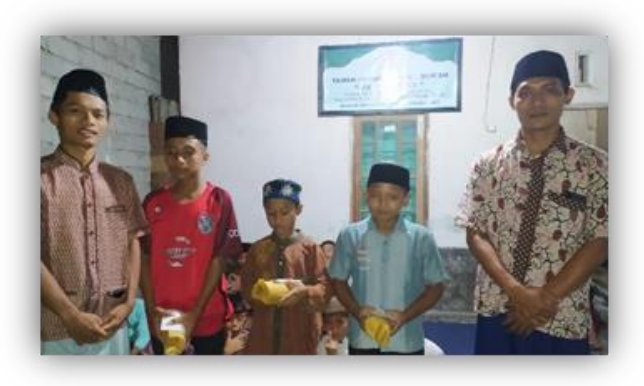

Gambar 8. Penyerahan Hadiah Lomba di TPQ Ambengan

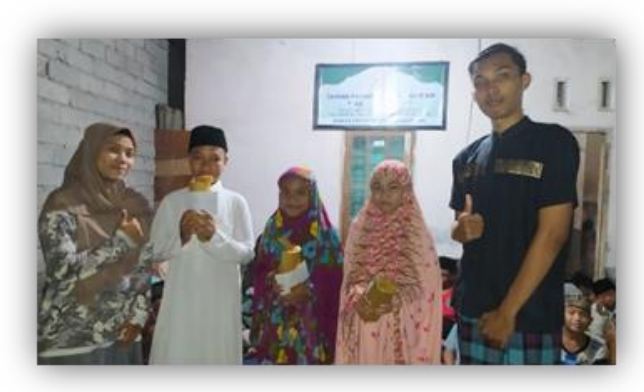

Gambar 9. Penyerahan Hadiah Lomba di TPQ Ambengan

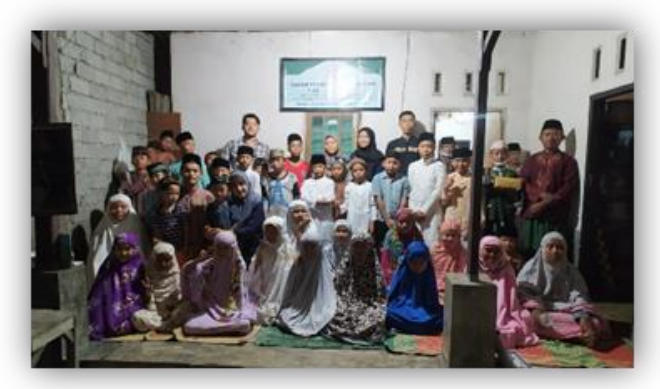

Gambar 10. Foto Bersama di TPQ Ambengan
3) Jumat 2B (Bebersih-Berbagi)

Mengingat kondisi dengan keadaan pandemi seperti saat ini, sarana umum beserta masyarakat harus selalu dijaga serta menjaga kebersihan dan kesehatannya. Oleh karena itu, dilakukannya kegiatan pembersihan masjid dan pembagian masker setiap hari Jumat di Masjid Jami AlIttihad Desa Labuhan Haji.

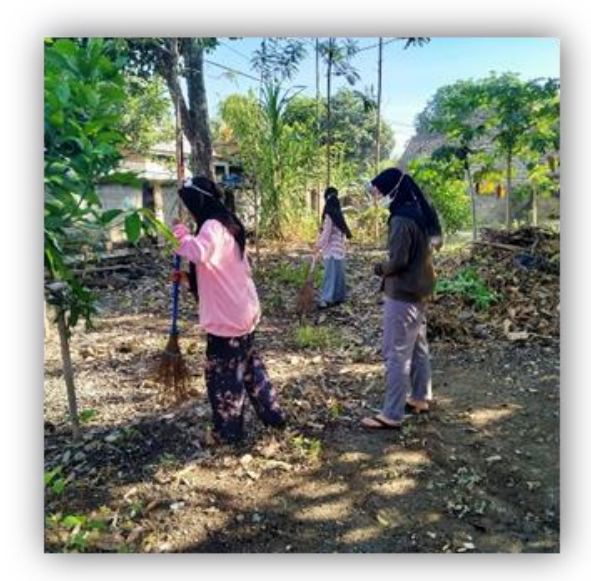

Gambar 11. Pembersihan Masjid Jami Al-Ittihad Desa Labuhan Haji

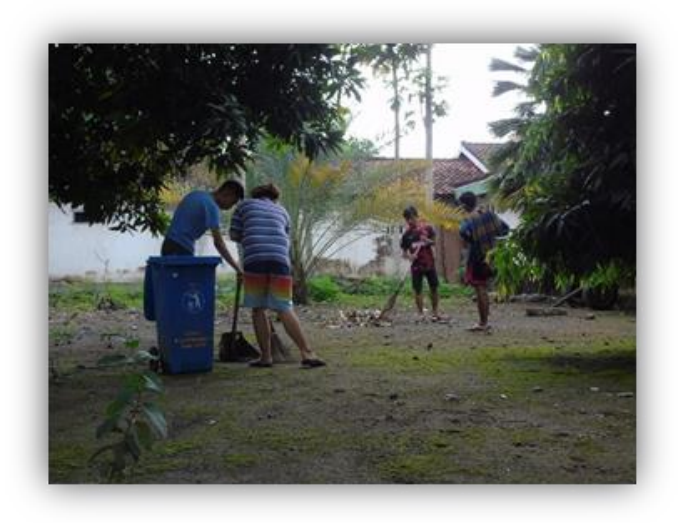

Gambar 12. Pembersihan Masjid Jami Al-Ittihad Desa Labuhan Haji 


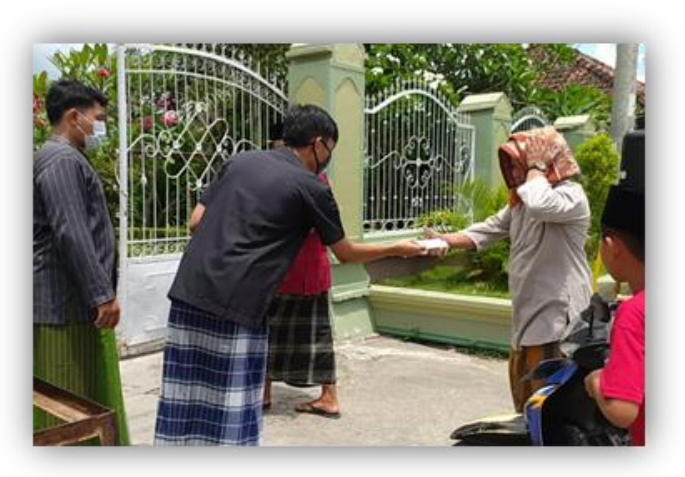

Gambar 13. Pembagian Masker di Masjid Jami Al-Ittihad Desa Labuhan Haji

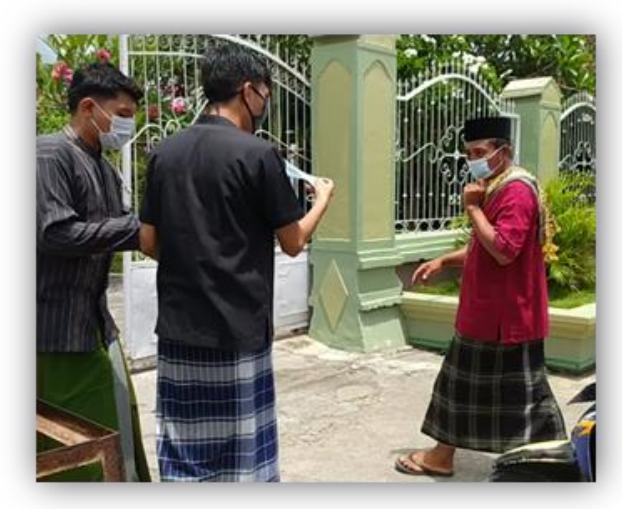

Gambar 14. Pembagian Masker di Masjid Jami Al-Ittihad Desa Labuhan Haji

4) Pembuatan Label Produk UMKM

Kemasan dan label dari suatu produk merupakan elemen yang sangat penting dalam penjualan dan pemasaran produk. Kami menyadari bahwa kemasan dan label dari beberapa produk pangan UMKM di Desa Labuhan Haji belum memenuhi standar tersebut.

Oleh karena itu, dilakukannya rebranding kemasan dan label dari beberapa produk pangan UMKM di Desa Labuhan Haji seperti kerupuk rumput laut, teh kelor, terasi udang, pilus rumput laut, dan dodol rumput laut dengan tujuan dan harapan agar produk-produk pangan tersebut layak dijual dan dipasarkan secara lokal, nasional maupun global. Selain itu, kelak ketika program TDC sudah dibangun di Desa Labuhan Haji, produk-produk pangan tersebut dapat menjadi produk unggulan dari Desa Labuhan Haji.

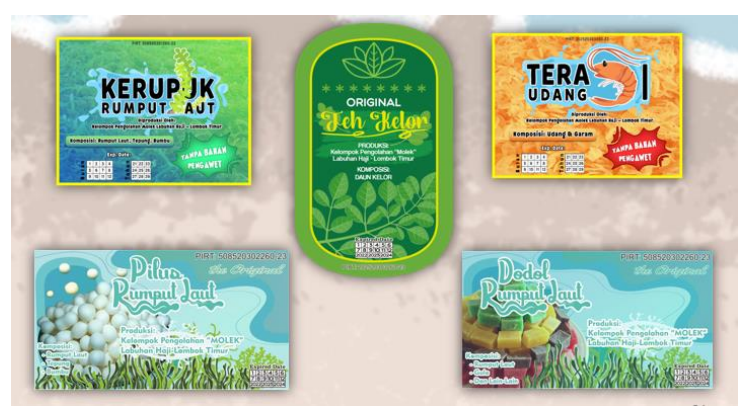

Gambar 15. Rebranding Kemasan dan Label Produk-produk Pangan UMKM Desa Labuhan Haji

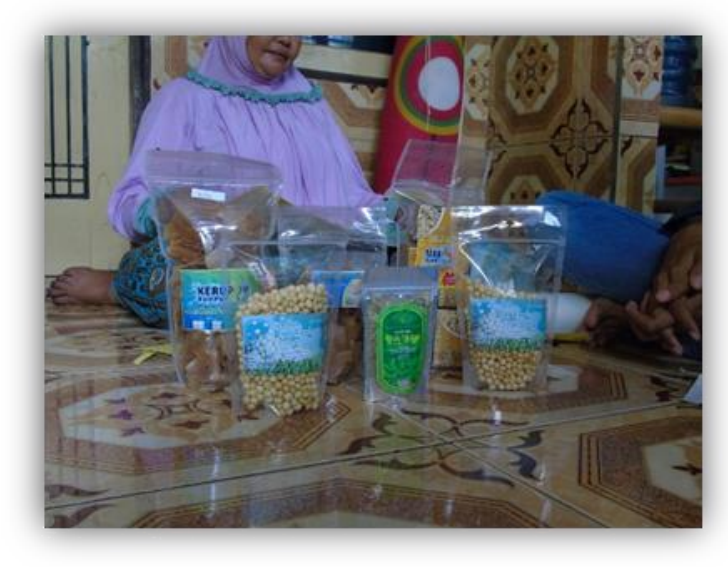

Gambar 16. Rebranding Kemasan dan Label Produk-produk Pangan UMKM Desa Labuhan Haji

5) Pembuatan Bak Sampah dan Pembersihan Pantai

Desa Labuhan Haji merupakan suatu desa yang dekat dengan pantai dan laut serta sangat berpotensi menjadi desa wisata. Namun, ketersediaan tempat pembuangan sampah yang masih jarang ditemui serta tingkat kesadaran masyarakat yang masih rendah akan pentingnya untuk menjaga kebersihan lingkungan menjadi salah satu penyebab pantai dan laut Desa Labuhan Haji menjadi cukup kotor dan kurang terawat. 
Maka dari itu, dilakukannya small movement yaitu pembuatan bak sampah sebanyak 10 buah dan kegiatan pembersihan pantai bersama Pokdarwis Desa Labuhan Haji yang dilakukan pada minggu terakhir kegiatan KKN dengan tujuan dan harapan meningkatkan kesadaran masyarakat Desa Labuhan Haji untuk pentingnya menjaga kebersihan lingkungan sekitar sehingga kelak Desa Labuhan Haji dapat menjadi desa wisata dengan pengunjung dari lokal, nasional, hingga global.

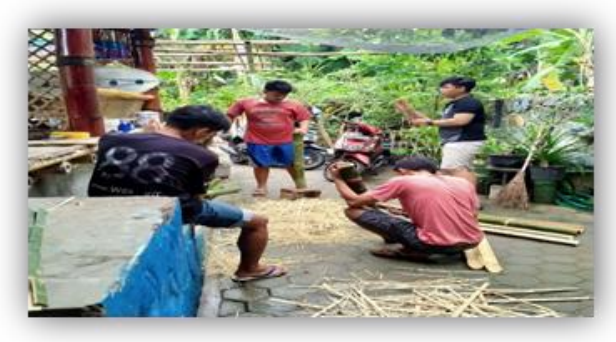

Gambar 17. Pembuatan Bak Sampah

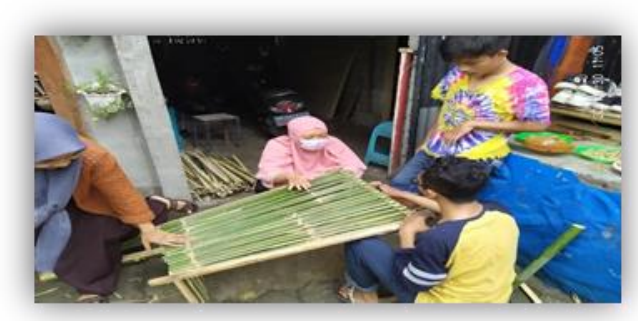

Gambar 18. Pembuatan Bak Sampah

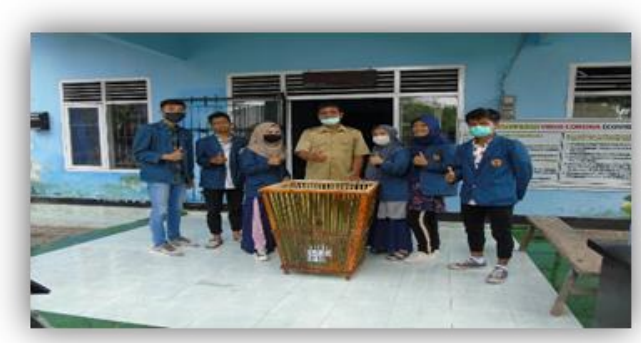

Gambar 19. Penyerahan Bak Sampah di Kantor Desa Labuhan Haji

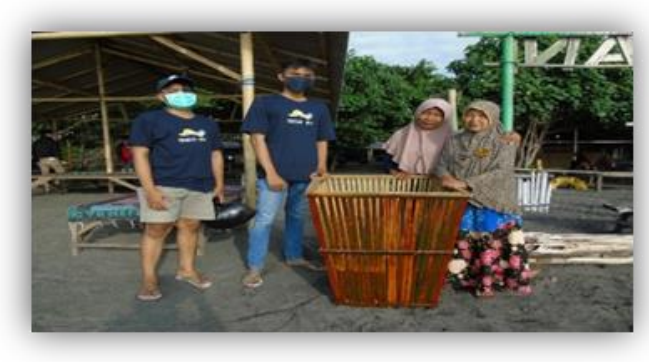

Gambar 20. Penyerahan Bak Sampah di Beberapa Titik di Pinggir Pantai

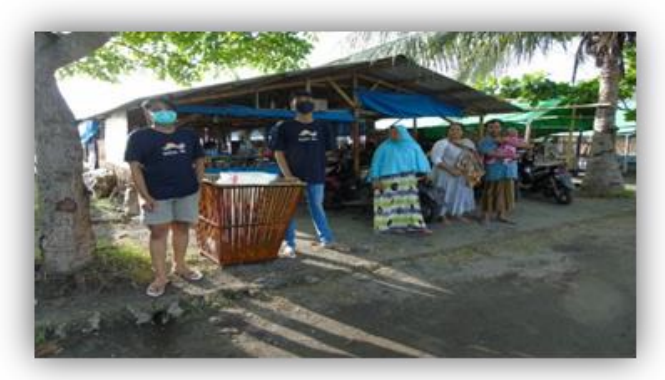

Gambar 21. Penyerahan Bak Sampah di Beberapa Titik di Pinggir Pantai

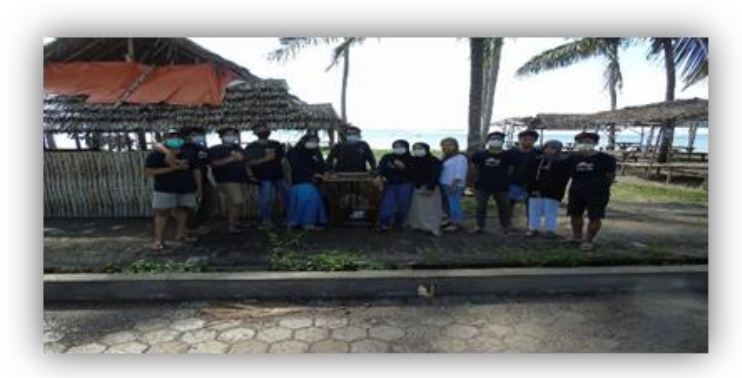

Gambar 22. Penyerahan Bak Sampah di Beberapa Titik di Pinggir Pantai 


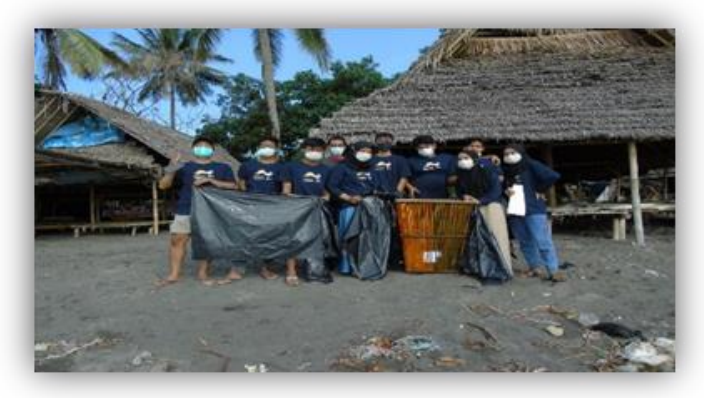

Gambar 23. Pembersihan Pantai Labuhan Haji

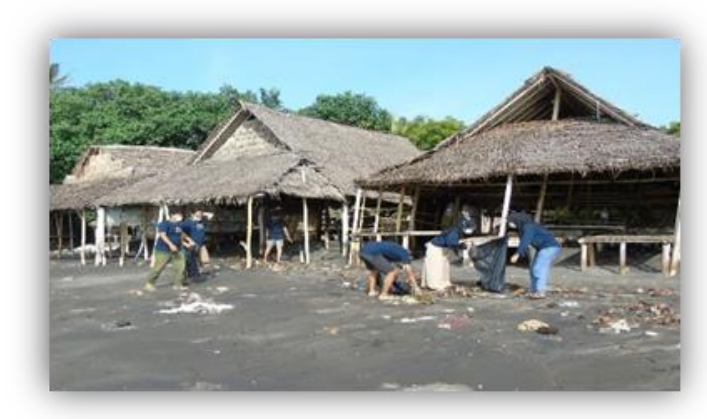

Gambar 24. Pembersihan Pantai Labuhan Haji

6) Konsultasi KKN dengan DPL

Melakukan kegiatan konsultasi dengan DPL bapak Dr. Drs. H. Ahmad Jupri, M.Eng untuk membahas terkait programprogram kerja yang akan kami laksanakan di desa labuhan haji.

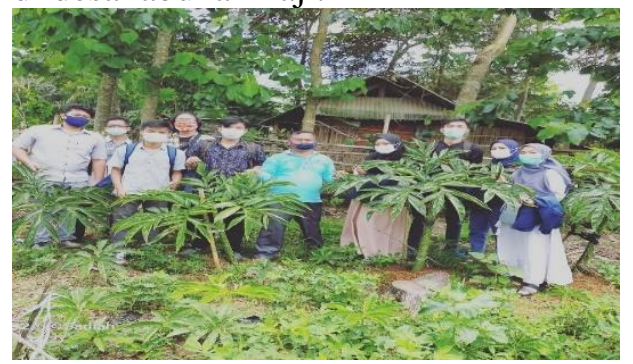

Gambar 38. Konsultasi dengan DPL

\section{Kesimpulan}

\footnotetext{
Pengelolaan data penduduk desa di desa Labuan Haji sudah sangat bagus dalam pendokumentasian namun kurang secara digitalisasi sehingga ketika pemerintah pusat meminta data tertentu yang diperuntukan untuk suatu program akan membuat staff administrasi desa kewalahan
}

dalam penginputan data. Penanganan pengelolaan data sudah sangat membantu dalam mempermudahkan staff desa dalam penginputan data penduduk desa dengan bantuan web SID yang sudah diaktivasi. Dengan begitu staff desa akan mudah mengelola data penduduk dan masyarakat desa juga mudah dalam mencari informasi tentang Desa Labuan Haji.

\section{Ucapan Terima Kasih}

Kami mengucapkan terimakasih kepada Bapak Pahminuddin, selaku Kepala Desa Labuhan Haji, Bapak Saifuddin Zuhri selaku Sekretaris Desa Labuhan Haji, Bapak Yadin Amrullah selaku Kepala Urusan Desa Labuhan Haji, Bapak Dr. Drs. Ahmad Jupri, M.Eng. selaku dosen pembimbing lapangan, dan seluruh masyarakat yang ada di Desa Labuhan Haji serta semua pihak yang telah membantu selama kegiatan KKN berlangsung.

\section{Daftar Pustaka}

Arikunto, Suharsimi.2010. Prosedur PenelitianSuatu Pendekatan Praktik. Jakarta: Rineka Cipta.

Fathoni, Abdurrahman. 2006. Organisasi Dan Manajemen Sumber Daya Manusia. Jakarta : PT Rineka Cipta

Mason, J. 2002. Qualitative Researching ( $2^{\text {nd }}$ Edition), Sage Publication, London.

Merriam, S.B. 2015. Introduction to Qualitative Research and Case Study. San Francisco, Josey-Bass Inc.

Sugiyono. 2012. Metode Penelitian Kuantitatif Kualitatif dan R\&B. Bandung: A Ifabeta 